\title{
Potential misidentifications of two climate indicator species of the marine arctic ecosystem: Calanus glacialis and $C$. finmarchicus
}

\author{
T. M. Gabrielsen · B. Merkel • J. E. Søreide • \\ E. Johansson-Karlsson · A. Bailey $\cdot$ D. Vogedes \\ H. Nygård $\cdot \emptyset$. Varpe $\cdot$ J. Berge
}

Received: 8 January 2012/Revised: 10 May 2012/Accepted: 10 May 2012

(C) The Author(s) 2012. This article is published with open access at Springerlink.com

\begin{abstract}
Calanoid copepods of the genus Calanus represent an important, nutrient-rich food source for a multitude of Arctic marine organisms. Although morphologically very similar, their life histories and ecological roles differ. Because the distribution of Calanus glacialis and C. finmarchicus corresponds to Arctic and Atlantic water masses, respectively, they are regularly used as climate indicators. A correct identification of these species is therefore necessary in many ecological, environmental and climatological studies. In this study, we aimed at validating the traditionally used morphological characteristics (combining prosome length and copepodite stage) for separation of species of Calanus by using molecular tools (PCR-RFLP of the $16 \mathrm{~S}$ mtDNA). A total of 418 specimens of copepodite stages CIV, $\mathrm{CV}$ and CVI(af) from three Arctic fjords have been identified both morphologically and genetically. We find that the morphological identification systematically overestimates the abundance of $C$. finmarchicus at the expense of C. glacialis. Hence, parts of the $C$. glacialis populations are found to be structurally smaller and the within population size range thus larger than previously assumed. Consequently, using the traditional morphological species delimitation poses a serious problem in the use of these two species as
\end{abstract}

T. M. Gabrielsen $(\bowtie) \cdot$ B. Merkel · J. E. Søreide .

E. Johansson-Karlsson - A. Bailey · D. Vogedes · H. Nygård .

$\emptyset$. Varpe $\cdot$ J. Berge

University Centre in Svalbard, 9171 Longyearbyen, Norway

e-mail: tove.gabrielsen@unis.no

$\varnothing$. Varpe

Norwegian Polar Institute, Fram Centre, 9296 Tromsø, Norway

J. Berge

Faculty of Biosciences, Fisheries and Economics,

University of Troms $\varnothing, 9037$ Troms $\varnothing$, Norway indicators of Atlantic versus Arctic water masses and thus as climatic indicators. Furthermore, it obscures our understanding of the life history differences between the two species and of their relative importance as food for a number of ecologically and economically important species in the Arctic.

Keywords Molecular systematics - Identification · Prosome length $\cdot$ Structural size

\section{Introduction}

Calanus spp. dominate the biomass of the mesozooplankton community by up to 75-90 \% in Arctic and sub-Arctic seas (Mumm et al. 1999; Hays et al. 2005; Wassmann et al. 2006; Blachowiak-Samolyk et al. 2008), and these herbivores represent an energy-rich food source of fundamental importance for a number of ecologically and commercially important species such as polar cod (e.g. Lønne and Gulliksen 1989; Renaud et al. 2012), little auk (Steen et al. 2007; Karnovsky et al. 2008), bowhead whales (Weslawski et al. 2000) and for large pelagic fish stocks of the subArctic North Atlantic (Varpe et al. 2005). The difference in size and energy content of Calanus glacialis and C. finmarchicus suggests that the two species support different arctic food webs (Weslawski et al. 2000; Falk-Petersen et al. 2009).

In the European Arctic, Calanus spp. are regarded as biological indicators of Arctic (Calanus glacialis and C. hyperboreus) and Atlantic (C. finmarchicus) water masses, respectively (Kwasniewski et al. 2003; Wassmann et al. 2006; Daase et al. 2007). Calanus hyperboreus Krøyer is an Arctic deep-water species with the Greenland Sea and the Arctic Ocean as its core distribution areas 
(Hirche 1991; Mumm et al. 1999). The smaller C. glacialis Jaschnov is an Arctic shelf species, whereas the smallest C. finmarchicus Gunnerus is an Atlantic species that occurs in the Arctic closely associated with the distribution of Atlantic water (Jaschnov 1970; Daase et al. 2007; Søreide et al. 2008).

Biological indicator species play a prominent role in understanding the effects of climate fluctuations on ecosystems. The Arctic region experiences substantial climatic oscillations on annual and decadal scales, and is predicted to experience large and rapid future climate changes (Post et al. 2009). A common prediction of the impact of climate change on biology is changes in species distributions, such as northward shifts of species as temperature increases (Wassmann et al. 2011). In the marine system, significant indicator species are of particular interest for tracing a potential Atlantification of the arctic water masses due to climate warming and sea ice loss (Wassmann et al. 2006). It has been postulated that a warmer climate would expand the distribution of $C$. finmarchicus northwards into waters traditionally dominated by $C$. glacialis and $C$. hyperboreus (Reygondeau and Beaugrand 2011; Slagstad et al. 2011; Wassmann et al. 2011), leading to a potential ecosystem shift in the arctic food web (Falk-Petersen et al. 2007). In the light of their importance as climate indicators and their key role in the arctic marine food web, it is imperative that the Calanus species can be identified correctly and that their species ranges and life histories are well understood.

The delimitation of the North Atlantic Calanus species relies mainly on few and subtle morphological characteristics. The largest of the three arctic species, C. hyperboreus, can be separated from the two others by an acute process on the 5th metasome segment in copepodite stages CIV, CV and CVI. There are also a few diagnostic taxonomical characters on the fifth pair of swimming legs that can be used to separate the adults of Calanus glacialis and C. finmarchicus (Frost 1974), although these two species are traditionally more difficult to distinguish compared to the much larger $C$. hyperboreus. The diagnostic taxonomical characters are time-consuming to use, and the Arctic Calanus spp. of all stages are therefore traditionally separated based on prosome length, with the separation of the species being based on the frequency distribution of prosome size within each copepodite stage. (e.g. Unstad and Tande 1991; Kwasniewski et al. 2003; Arnkvaern et al. 2005; Forest et al. 2011).

The Barents Sea-Svalbard region is a transition zone between warm and saline Atlantic water and cold and less saline Arctic water and represents a region of sympatry for C. glacialis and C. finmarchicus. The two species were recently shown to overlap in size in areas of sympatric distribution in the Canadian Arctic (Parent et al. 2011) and in the Irminger Sea (Lindeque et al. 2006), thus pointing at a potential challenge to correctly identify the species using the traditional method of prosome length. In this study, we use the molecular tools developed by Lindeque et al. (1999) to test for the reliability of morphometric species identification of stages CIV, CV and adult females of $C$. finmarchicus and C. glacialis in the European Arctic. In this region, many past and ongoing studies have relied on C. finmarchicus and C. glacialis as climate change indicator species (e.g. Wassmann et al. 2006; Slagstad et al. 2011). Hence, we also test the reliability of using the two species as endpoints in studies of effects of climate change (e.g. Beaugrand et al. 2002; Slagstad et al. 2011).

\section{Materials and methods}

Calanus copepods were collected from Rijpfjorden (N $80^{\circ}$ 17.034 E $\left.22^{\circ} 18.149\right)$, Kongsfjorden (N $78^{\circ} 57.754 \mathrm{E} 11^{\circ}$ 45.556) and Billefjorden (N $78^{\circ} 35.7$ E $16^{\circ} 30.36$; Fig. 1) in Svalbard using WP2 nets with $0.25 \mathrm{~m}^{2}$ opening and $200 \mu \mathrm{m}$ mesh size. A total of 419 individuals were picked, rinsed in distilled water and photographed using a digital video camera (Sony HDR-HC7E) mounted to a stereomicroscope (Leica MZ16) before they were fixed in 80-96 \% Ethanol and stored in $80 \%$ Ethanol until analysis. The copepodite stage and prosome length (from the tip of the cephalosome to the distal lateral end of the last thoracic segment) of each individual was identified from the digital photos and measured using the free image analysis software ImageJ (V 1.42q) (http://rsbweb.nih.gov/ij) as described in Vogedes et al. (2010).

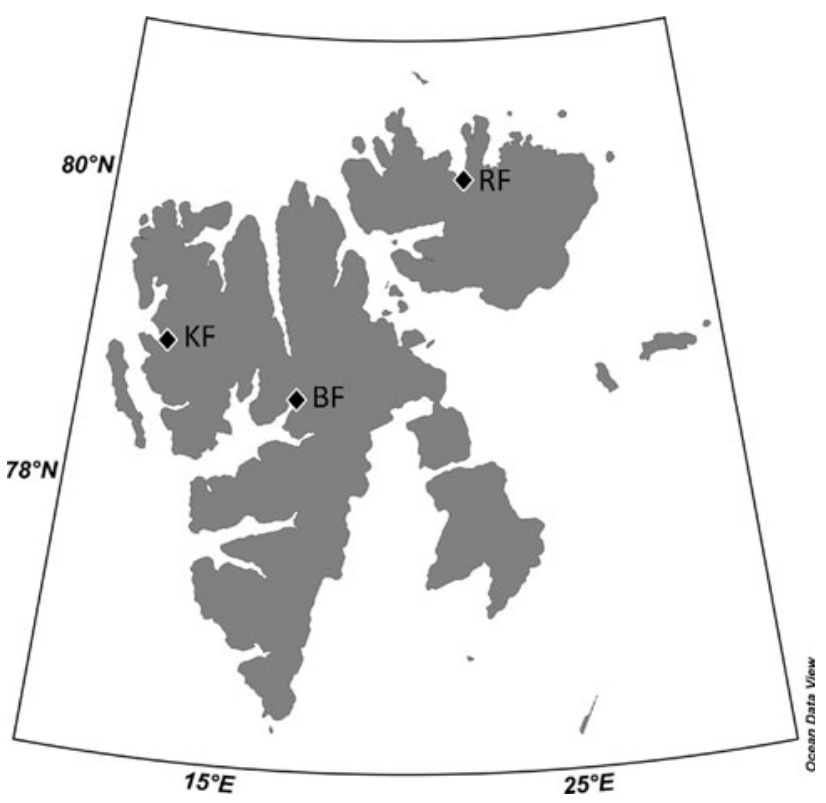

Fig. 1 Map of Svalbard and the sampled populations in Billefjorden $(B A B)$, Kongsfjorden $(K F)$ and Rijpfjorden $(R F)$ 
The analysed individuals were selected to cover the prosome lengths known to overlap among the different copepodite stages of Calanus glacialis and C. finmarchicus (Kwasniewski et al. 2003 [Kongsfjorden]; Arnkvaern et al. 2005 [Billefjorden]). Samples were collected in the autumn of 2009 (all three fjords) as well as in Billefjorden in the spring of 2009 and 2010. In the spring of 2010, sampling was done at two different dates in Billefjorden. The analysed individuals represented the copepodite stages CIV (127 specimens), CV (177 specimens) and CVI (af; 113 specimens) with the most individuals analysed from Billefjorden (329 specimens). During the 2010 field work in Billefjorden, the prosome length distribution of the whole population was estimated at each date separately, in addition to the sampling of individuals for genetic analyses.

Prior to DNA extraction, single individuals were rinsed well and hydrated in distilled water over night. DNA was extracted using the EZNA kit (Omega Bio-Tek Inc.) according to the manufacturer's recommendation. PCR reactions were performed in volumes of $25 \mu \mathrm{l}$ containing $200 \mu \mathrm{M}$ dNTPs, $0.4 \mu \mathrm{M}$ of each primer (16SAR; Palumbi and Benzie 1991 and 16SB2R; Lindeque et al. 1999), 1× PCR buffer, 0.5U DreamTaq polymerase (Fermentas Life Sciences) and $2 \mu$ lextracted DNA. The cycling conditions included an initial denaturation step at $95{ }^{\circ} \mathrm{C}$ for $3 \mathrm{~min}$ followed by 35 cycles of $94{ }^{\circ} \mathrm{C}$ for $30 \mathrm{~s}, 54{ }^{\circ} \mathrm{C}$ for $30 \mathrm{~s}$ and $72{ }^{\circ} \mathrm{C}$ for $60 \mathrm{~s}$. A final extension phase of $10 \mathrm{~min}$ at $72{ }^{\circ} \mathrm{C}$ was allowed, and the samples were then stored at $4{ }^{\circ} \mathrm{C}$ until use. The PCR products were cut using the restriction enzymes VspI and DdeI according to the manufacturer's recommendation (Fermentas Life Sciences), and the products were separated on $2 \%$ agarose gels and identified to $C$. glacialis or $C$. finmarchicus according to the restriction patterns (Lindeque et al. 1999).

\section{Results}

Our analyses show that $C$. glacialis is frequently misidentified as $C$. finmarchicus when the species delimitation is based solely on prosome length (Table 1; Fig. 2). Genetic species delimitation based on the PCR-RFLP pattern identified 329 individuals to $C$. glacialis and 88 individuals to $C$. finmarchicus, whereas size-morphological species delimitation identified 234 individuals to $C$. glacialis and 183 individuals to $C$. finmarchicus. Overall, $25.7 \%$ of the analysed individuals were wrongly identified, and only $5.6 \%$ of the wrongly identified individuals were $C$. finmarchicus misidentified as $C$. glacialis. The misidentification was greatest for adult females, followed by $\mathrm{CV}$ and CIV.

\section{Copepodite stage IV}

A total of 127 individuals of copepodite stage CIV (1.5-2.7 mm PL; Fig. 2) were analysed, of which 95 were
Table 1 A comparison of morphological (prosome length) and genetic (PCR-RFLP) species delimitation of $C$. finmarchicus and $C$. glacialis with a calculation of the percentage of wrongly identified specimens in each copepodite stage as well as a calculation of the percentage overestimation of $C$. finmarchicus ( $\mathrm{C}$ fin (morph) $-\mathrm{C}$ fin (gen))/C fin (gen)

\begin{tabular}{|c|c|c|c|c|c|c|c|c|c|c|c|}
\hline & \multirow[t]{2}{*}{$N$} & \multicolumn{4}{|c|}{ Morphological delimitation } & \multicolumn{4}{|c|}{ Genetic delimitation } & \multirow{2}{*}{$\begin{array}{l}\% \text { Wrongly } \\
\text { identified }\end{array}$} & \multirow{2}{*}{$\begin{array}{l}\% \text { Overestimation } \\
\text { of C. finmarchicus }\end{array}$} \\
\hline & & finm no & finm \% & glac no & glac \% & finm no & finm \% & glac no & glac \% & & \\
\hline \multicolumn{12}{|c|}{ Billefjorden } \\
\hline CIV & 103 & 35 & 34.0 & 68 & 66.0 & 20 & 19.4 & 83 & 80.6 & 20.4 & 75.0 \\
\hline $\mathrm{CV}$ & 120 & 75 & 62.5 & 45 & 37.5 & 42 & 35.0 & 78 & 65.0 & 29.2 & 78.6 \\
\hline CVI(af) & 106 & 38 & 35.8 & 68 & 64.2 & 2 & 1.9 & 104 & 98.1 & 34.0 & $1,800.0$ \\
\hline \multicolumn{12}{|c|}{ Kongsfjorden } \\
\hline CIV & 17 & 13 & 76.5 & 4 & 23.5 & 11 & 64.7 & 6 & 35.3 & 11.8 & 18.2 \\
\hline $\mathrm{CV}$ & 21 & 11 & 52.4 & 10 & 47.6 & 6 & 28.6 & 15 & 71.4 & 23.8 & 83.3 \\
\hline CVI(af) & 5 & 4 & 80.0 & 1 & 20.0 & 4 & 80.0 & 1 & 20.0 & $\mathrm{n} / \mathrm{a}$ & $\mathrm{n} / \mathrm{a}$ \\
\hline \multicolumn{12}{|c|}{ Rijpfjorden } \\
\hline CIV & 7 & 0 & 0.0 & 7 & 100.0 & 1 & 14.3 & 6 & 85.7 & $\mathrm{n} / \mathrm{a}$ & $\mathrm{n} / \mathrm{a}$ \\
\hline $\mathrm{CV}$ & 36 & 7 & 19.4 & 29 & 80.6 & 2 & 5.6 & 34 & 94.4 & 13.9 & 250.0 \\
\hline CVI(af) & 2 & 0 & 0.0 & 2 & 100.0 & 0 & 0.0 & 2 & 100.0 & $\mathrm{n} / \mathrm{a}$ & $\mathrm{n} / \mathrm{a}$ \\
\hline \multicolumn{12}{|c|}{ All populations } \\
\hline CIV & 127 & 48 & 37.8 & 79 & 62.2 & 32 & 25.2 & 95 & 74.8 & 18.9 & 50.0 \\
\hline $\mathrm{CV}$ & 177 & 93 & 52.5 & 84 & 47.5 & 50 & 28.2 & 127 & 71.8 & 25.4 & 86.0 \\
\hline CVI(af) & 113 & 42 & 37.2 & 71 & 62.8 & 6 & 5.3 & 107 & 94.7 & 33.6 & 600.0 \\
\hline
\end{tabular}


Billefjorden
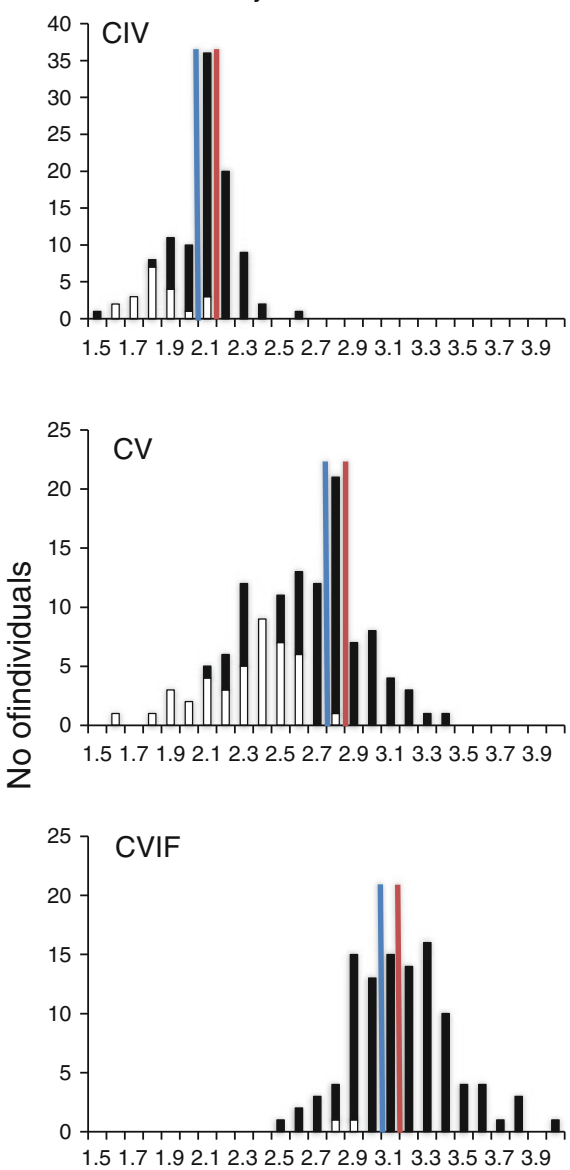

Prosome length $(\mathrm{mm})$

Kongsfjorden


Fig. 2 Prosome length $(P L)$ distribution of the Calanus spp. specimens of copepodite stages CIV, CV and CVI (af) analysed using PCR-RFLP of the 16S mtDNA gene. The coloured lines represent the prosome lengths utilized to distinguish the two species according to Arnkværn et al. (2005; blue line) and Kwasniewski et al. (2003; red line) identified as $C$. glacialis and 32 were identified as $C$. finmarchicus based on the PCR-RFLP pattern. Overall, $18.9 \%$ of the individuals were wrongly identified using species delimitation based on the prosome length. The overestimation of $C$. finmarchicus was most pronounced in Billefjorden with $75 \%$ of the investigated specimens wrongly identified as $C$. finmarchicus (Table 1).

\section{Copepodite stage V}

A total of 177 specimens of copepodite stage CV (1.6$3.5 \mathrm{~mm}$ PL; Fig. 2) were analysed. Of these, 127 were identified as $C$. glacialis and 50 were identified as $C$. finmarchicus based on the PCR-RFLP pattern. Overall, $25.4 \%$ of the individuals were wrongly identified based on morphological species delimitation (Table 1), most severely so in our Rijpfjorden case.

\section{Adult females}

A total of 113 adult females (2.4-4.0 mm PL; Fig. 2) were analysed. Of these, 107 individuals were identified as C. glacialis and only 6 were identified as $C$. finmarchicus based on the PCR-RFLP pattern. Overall, $33.6 \%$ of the individuals were misidentified using morphological species delimitation, and there was a distinct overestimation of C. finmarchicus over C. glacialis (Table 1). The overestimation of $C$. finmarchicus was most pronounced among the adult females collected in Billefjorden where the presence of C. finmarchicus was overestimated by $1,800 \%$ (Table 1 ).

Prosome length distribution of the Billefjorden population

The prosome length distributions of the Billefjorden $\mathrm{Cal}$ anus population collected at two sampling dates in 2010 
March 2010
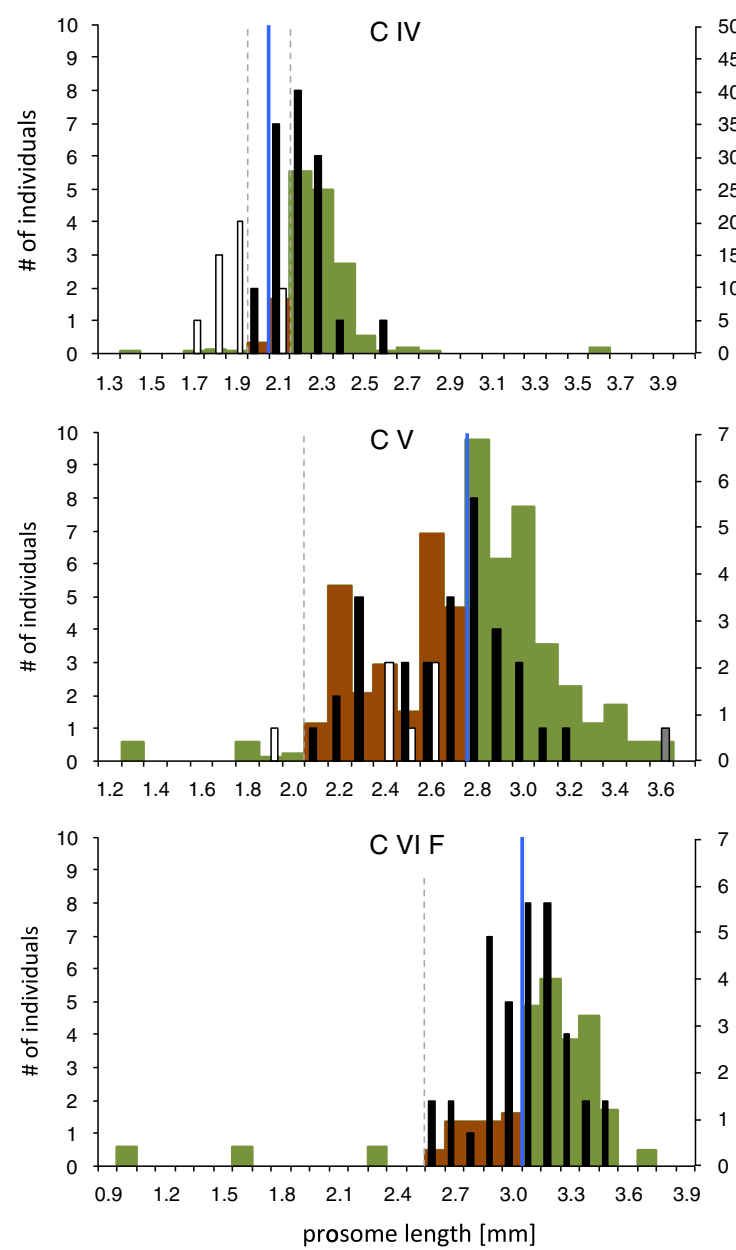

Fig. 3 Prosome length $(P L)$ distribution of the two Billefjorden samples of Calanus spp. copepodite stages CIV, CV and CVI (af) for which the PL of the whole sample was analysed. The samples were collected in March of 2010 (left three panels) and in April of 2010 (right three panels), and included samples from both deep and surface waters (cf. Fig. 1). The blue line represents the prosome length utilized to distinguish the two species according to Arnkvaern et al. (2005), the green bars are the total amount of specimens collected

show that a large part of the population is within the size range where identification based solely on size morphology is difficult (Fig. 3). Based on the minimum and maximum of misidentified PL as shown in Fig. 3, an average of $14 \%$ of the total population of CIV, $42 \%$ of the total population of $\mathrm{CV}$ and $13 \%$ of the total population of CVI (af) in March and April of 2010 were within the prosome length size range where morphological identification was uncertain (Table 2).

\section{Discussion}

The prosome length variation identified within $C$. glacialis in this study, with a higher than expected number of small
April 2010
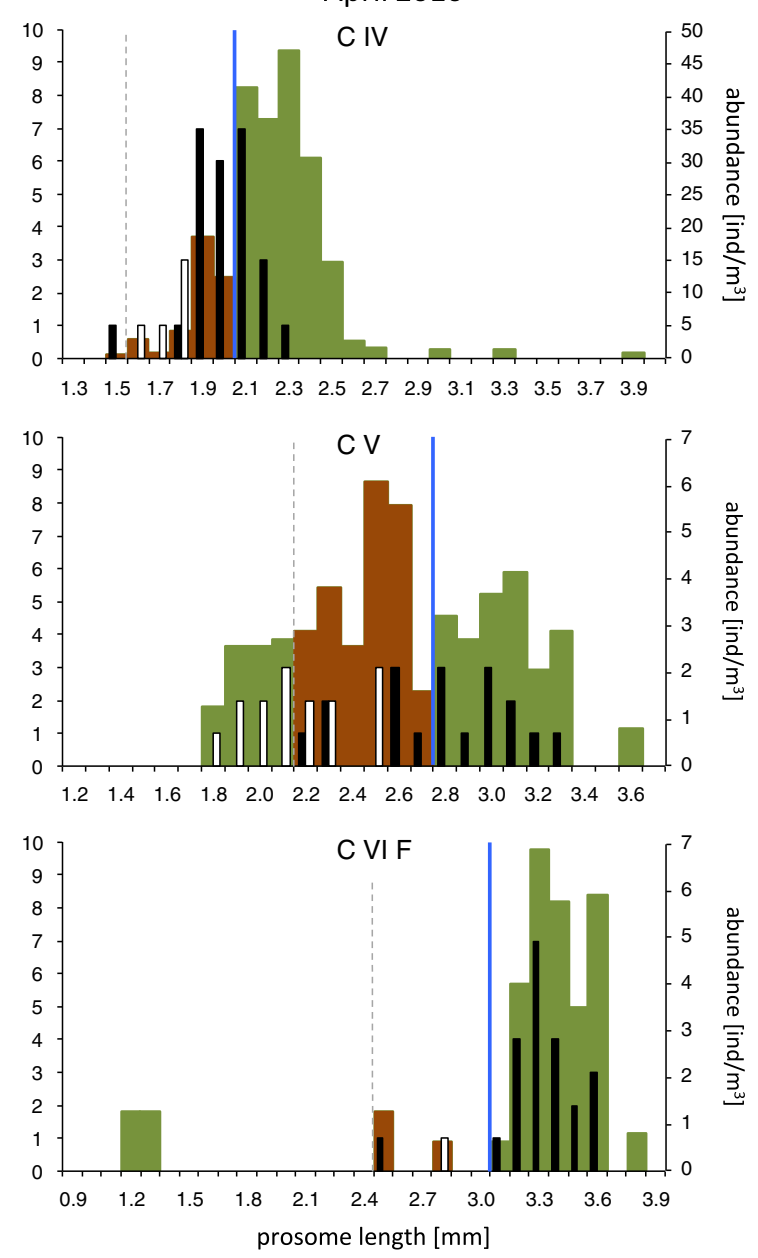

(scale on the right), the white bars are the number of genetically identified $C$. finmarchicus specimens (scale on the left) and the black bars are the number of genetically identified $C$. glacialis specimens (scale on the left). Brown background individuals of PL where the species id was uncertain based solely on prosome size. The dotted lines show the overlap region based on genetic identification of species

specimens, may compromise our understanding of the ecology and distribution of this species and points to a serious problem in the species delimitation of particularly C. glacialis and C. finmarchicus. Because structural size is a plastic trait in most organisms and in zooplankton a result of both temperature-dependent developmental time and growth (e.g. McLaren et al. 1988), variability in this characteristic is not unexpected. Also, life history strategies are typically state dependent (McNamara and Houston 1996) and structural size may thus vary between and within populations due to strategic fitness-maximizing processes (cf. Varpe 2012). In fact, analyses of the length-frequency distribution of the arctic Calanus spp. in Svalbard waters show slightly different size distributions of the two species in different fjord systems (Kwasniewski et al. 2003; 
Table 2 The percentage of the total population of Calanus spp. collected in March and April of 2010 that were of a prosome length (PL) where species id was difficult due to overlapping size ranges of $C$. glacialis and C. finmarchicus

\begin{tabular}{|c|c|c|c|c|c|c|c|c|c|}
\hline \multirow[t]{2}{*}{ Individuals } & \multicolumn{3}{|c|}{ March } & \multicolumn{3}{|l|}{ April } & \multicolumn{3}{|c|}{ Average (March-April) } \\
\hline & CIV & $\mathrm{CV}$ & CVI(af) & CIV & $\mathrm{CV}$ & CVI(af) & CIV & $\mathrm{CV}$ & CVI(af) \\
\hline Total no & 1,639 & 823 & 357 & 3,224 & 824 & 448 & 2,432 & 824 & 402 \\
\hline Fraction within total & 195 & 342 & 69 & 536 & 355 & 26 & 366 & 348 & 47 \\
\hline$\%$ & 12 & 42 & 19 & 17 & 43 & 6 & 14 & 42 & 13 \\
\hline finm no & 58 & 358 & 93 & 536 & 483 & 59 & 297 & 420 & 76 \\
\hline Fraction within finm & 32 & 342 & 69 & 536 & 355 & 26 & 284 & 348 & 47 \\
\hline$\%$ & 55 & 96 & 74 & 100 & 73 & 44 & 78 & 84 & 59 \\
\hline glac no & 1,581 & 465 & 264 & 2,688 & 341 & 389 & 2,135 & 403 & 326 \\
\hline Fraction within gla & 163 & 0 & 0 & 0 & 0 & 0 & 82 & 0 & 0 \\
\hline$\%$ & 10 & 0 & 0 & 0 & 0 & 0 & 5 & 0 & 0 \\
\hline Individuals & \multicolumn{2}{|c|}{ Within total pop } & \multicolumn{4}{|c|}{ Within finm (morph. delimitation) } & \multicolumn{3}{|c|}{ Within glac (morph. delimitation) } \\
\hline \multicolumn{10}{|l|}{ March } \\
\hline CIV $(\%)$ & \multicolumn{2}{|l|}{12} & \multicolumn{2}{|c|}{55} & & & \multicolumn{3}{|l|}{10} \\
\hline $\mathrm{CV}(\%)$ & \multicolumn{2}{|l|}{42} & \multicolumn{2}{|c|}{96} & & & \multicolumn{3}{|l|}{0} \\
\hline CVI(af) $(\%)$ & \multicolumn{2}{|l|}{19} & \multicolumn{2}{|c|}{74} & & & \multicolumn{3}{|l|}{0} \\
\hline \multicolumn{10}{|l|}{ April } \\
\hline CIV $(\%)$ & \multicolumn{2}{|l|}{17} & \multicolumn{2}{|c|}{100} & & & \multicolumn{3}{|l|}{0} \\
\hline $\mathrm{CV}(\%)$ & \multicolumn{2}{|l|}{43} & & & & & 0 & & \\
\hline CVI(af) $(\%)$ & 6 & & & & & & 0 & & \\
\hline Average & & & & & & & & & \\
\hline CIV $(\%)$ & 14 & & & & & & 5 & & \\
\hline $\mathrm{CV}(\%)$ & 42 & & & & & & 0 & & \\
\hline CVI(af) $(\%)$ & 13 & & & & & & 0 & & \\
\hline
\end{tabular}

Total no-total number of specimens of each stage and sampling date, fraction within total-number of specimens within the PL range where species id was difficult, finm no-number of $C$. finmarchicus specimens identified morphologically for each stage and sampling date, glac nonumber of $C$. glacialis specimens identified morphologically for each stage and sampling date, within finm-percentage of the population of $C$. finmarchicus found within the PL size range in which species id was difficult, within glac-percentage of the population of $C$. glacialis found within the PL size range in which species id was difficult

Arnkvaern et al. 2005; Daase et al. 2007; Weydmann and Kwasniewski 2008). The distinct overestimation of the abundance of $C$. finmarchicus over $C$. glacialis in all fjords and copepodite stages investigated around Svalbard was, however, unexpected. This result does support the results by Parent et al. (2011) for Calanus spp. off the Canadian coast and Lindeque et al. (2006) for Calanus spp. in the Irminger Sea that $C$. glacialis can have a smaller size than is commonly assumed in traditional species delimitation based on prosome length. Thus, wrongly identified material of this sibling species complex may be a problem throughout their distribution area.

The region within which the specimens are unequivocally identified, defined as the size classes where there are no discrepancies between the genetically and morphologically based identification, varies in time, space and among developmental stages (Figs. 2,3). The identification problem is thus not a stable phenomenon (Fig. 3), and the number of misidentifications varied between the two sampling periods in March and April in Billefjorden (Table 2). In March for the CV copepodites, almost half of the population was within the prosome length with a high degree of misidentifications (see also Table 2), whereas only one-third of the population was affected in April. Similarly, for the CIV stages, only very few individuals were within the size range affected by misidentifications in March, whereas almost one-third of the CIV stages could not be unequivocally identified using prosome length in April (Fig. 3; Table 2).

Increased sea water temperatures have generally been argued to be responsible for prosome size reductions in Calanus spp. (Kwasniewski et al. 2003). However, our results identifying smaller than expected $C$. glacialis in all fjords investigated with Kongsfjorden being mostly 
influenced by warm Atlantic water masses, Rijpfjorden being mostly influenced by cold Arctic water masses and Billefjorden consisting mostly of winter-cooled water close to freezing temperatures of sea water (Nilsen et al. 2008; Wallace et al. 2010) do not support such an argument. It has previously been shown that $C$. glacialis from the Arctic Ocean also harbour small specimens (adult females with prosome lengths down to $2.81 \mathrm{~mm}$; Frost 1974).

The mitochondrial marker utilized to separate Calanus species in the present study cannot be used to properly identify hybridization events between the species because mtDNA in general is uniparentally inherited. If hybridization between $C$. glacialis and $C$. finmarchicus does occur, we could expect to find hybrids with intermediate prosome lengths disturbing the general pattern of prosome length distributions. Hybridization thus offers a possible explanation to the observed pattern of $C$. glacialis specimens that are smaller than expected, although the complete lack of adult females in Billefjorden in our samples indicate that the hybridization pressure is low (at least in the sampled period), and hence that the size distribution represents a biological characteristic of the Calanus spp. populations in the examined waters.

An alternative explanation for the larger than expected range in prosome lengths of $C$. glacialis may be size differences resulting from variation in the length of its life cycle. Calanus glacialis usually has a 2-year life cycle, spawning in the spring of its third year (Falk-Petersen et al. 2009). Both 1- and 3-year life cycles have been observed, the first is probably more common at the southern fringes of its distribution area (Tande 1991). Calanus glacialis thus overwinters as either CIV or CV. The extended prosome length variation that we observed in $C$. glacialis may result from different lengths of life cycles, where populations/ specimens with 1-year life cycles would be expected to reach maturity at a smaller size compared to populations/ specimens with 2- or 3-year life cycles. The negative shift in prosome length identified in $C$. glacialis may thus result from variation in life history characteristics, with a 1-year life cycle dominating in the populations where we find a shift towards smaller size.

Berge et al. (2012) recently argued that in the presence of strong predation pressure, an adaptation towards shorter life cycles and thus smaller size is an evolutionary advantage enabling Calanus to reproduce under high predation pressure. The size variation in $C$. glacialis that we observe in this study may be an adaptation to predation, and one hypothesis to investigate further is if there is size (and thus life history) variation in $C$. glacialis in different regions with different selection pressure based on predation from fish.

Rapid shifts in the distribution of the two northern Calanus spp. have been both observed (Beaugrand et al.
2002) and predicted (Slagstad et al. 2011) within the Arctic. These shifts are generally assumed to be directly related to changes in temperature, although the mechanisms are not unequivocal (Kaartvedt 2008). The impact of the herein reported potential misidentification on our understanding of the relationship between climate change and the biology of the two Calanus spp., might thus be significant. Based on the common suggestion that the two species support two different food chains (Falk-Petersen et al. 2007) and that at least $C$. finmarchicus is restricted by a northern distribution limit (e.g. Beaugrand et al. 2002), it has become part of our general understanding of the Arctic marine system that $C$. finmarchicus will replace $C$. glacialis as the former expand northwards (see e.g. Slagstad et al. 2011). However, following the herein reported and that of Parent et al. (2011) overestimation of C. finmarchicus at the expense of $C$. glacialis, it will be important to map the extent of this problem, both at a spatial and temporal scale, in order to provide insight into potential consequences of the ongoing warming in the Arctic (Comiso et al. 2008).

Acknowledgments This study was financed by the University Centre in Svalbard, Norway. Four anonymous reviewers in addition to the chief editor made valuable comments to improve the manuscript.

Open Access This article is distributed under the terms of the Creative Commons Attribution License which permits any use, distribution, and reproduction in any medium, provided the original author(s) and the source are credited.

\section{References}

Arnkvaern G, Daase M, Eiane K (2005) Dynamics of coexisting Calanus finmarchicus, Calanus glacialis and Calanus hyperboreus populations in a high-Arctic fjord. Polar Biol 28:528-538

Beaugrand G, Ibanez F, Lindley JA, Reid PC (2002) Diversity of calanoid copepods in the North Atlantic and adjacent seas: species associations and biogeography. Mar Ecol-Prog Ser 232: $179-195$

Berge J, Gabrielsen TM, Moline M, Renaud PE (2012) Evolution of the arctic Calanus complex-an Arctic marine avocado? J Plankton Res 34:191-195

Blachowiak-Samolyk K, Søreide JE, Kwasniewski S, Sundfjord A, Hop H, Falk-Petersen S, Hegseth EN (2008) Hydrodynamic control of mesozooplankton abundance and biomass in northern Svalbard waters (79-81 degrees N). Deep-Sea Res Pt II 55:2210 2224

Comiso JC, Parkinson CL, Gersten R, Stock L (2008) Accelerated decline in the Arctic Sea ice cover. Geophys Res Lett 35:L01707

Daase M, Vik JO, Bagoien E, Stenseth NC, Eiane K (2007) The influence of advection on Calanus near Svalbard: statistical relations between salinity, temperature and copepod abundance. J Plankton Res 29:903-911

Falk-Petersen S, Timofeev S, Pavlov V, Sargent JR (2007) Climate variability and the effect on Arctic food chains. The role of Calanus. In: Ørbæk JR, Tombre T, Kallenborn R, Hegseth E, 
Falk-Petersen S, Hoel AH (eds) Arctic-Alpine ecosystems and people in a changing environment. Springer, Berlin, pp 147-166

Falk-Petersen S, Mayzaud P, Kattner G, Sargent J (2009) Lipids and life strategy of Arctic Calanus. Mar Biol Res 5:18-39

Forest A, Galindo V, Darnis G, Pineault S, Lalande C, Tremblay J-E, Fortier L (2011) Carbon biomass, elemental ratios (C:N) and stable isotopic composition (\{delta\}13C, \{delta $\} 15 \mathrm{~N})$ of dominant calanoid copepods during the winter-to-summer transition in the Amundsen Gulf (Arctic Ocean). J Plankton Res 33:161178

Frost BW (1974) Calanus marshallae, a new species of calanoid copepod closely allied to sibling species Calanus finmarchicus and Calanus glacialis. Mar Biol 26:77-99

Hays GC, Richardson AJ, Robinson C (2005) Climate change and marine plankton. TREE 20:337-344

Hirche HJ (1991) Distribution of dominant calanoid copepod species in the Greenland Sea during late fall. Polar Biol 11:351-362

Jaschnov WA (1970) Distribution of Calanus species in the seas of the Northern Hemisphere. Int Rev Gesamten Hydrobiol 55:197212

Kaartvedt S (2008) Photoperiod may constrain the effect of global warming in arctic marine systems. J Plankton Res 30:1203-1206

Karnovsky NJ, Hobson KA, Iverson S, Hunt GL (2008) Seasonal changes in diets of seabirds in the North Water Polynya: a multiple-indicator approach. Mar Ecol-Progr Ser 357:291-299

Kwasniewski S, Hop H, Falk-Petersen S, Pedersen G (2003) Distribution of Calanus species in Kongsfjorden, a glacial fjord in Svalbard. J Plankton Res 25:1-20

Lindeque PK, Harris RP, Jones MB, Smerdon G (1999) Simple molecular method to distinguish the identity of Calanus species (Copepoda: Calanoida) at any developmental stage. Mar Biol 133:91-96

Lindeque PK, Hay SJ, Heath MR, Ingvarsdottir A, Rasmussen J, Smerdon GR, Wanier JJ (2006) Integrating conventional microscopy and molecular analysis to analyse the abundance and distribution of four Calanus congeners in the North Atlantic. J Plankton Res 2:221-238

Lønne OJ, Gulliksen B (1989) Size, age and diet of polar cod, Boreogadus saida (Lepechin 1773), in ice covered waters. Polar Biol 9:187-191

McLaren IA, Sevigny JM, Corkett CJ (1988) Body sizes, development rates, and genome sizes among Calanus species. Hydrobiologia 167:275-284

McNamara JM, Houston AI (1996) State-dependent life histories. Nature 380:215-221

Mumm N, Auel H, Hanssen H, Hagen W, Richter C, Hirche HJ (1999) Breaking the ice: large-scale distribution of mesozooplankton after a decade of arctic and transpolar cruises. Polar Biol 21:64

Nilsen F, Cottier F, Skogseth R, Mattsson S (2008) Fjord-shelf exchanges controlled by ice and brine production: the interannual variation of Atlantic Water in Isfjorden, Svalbard. Cont Shelf Res 28:1838-1853

Palumbi SR, Benzie J (1991) Large mitochondrial DNA differences between morphologically similar Penaeid shrimp. Mol Mar Biol Biotech 1:27-34

Parent GJ, Plourde S, Turgeon J (2011) Overlapping size ranges of Calanus off the Canadian Arctic and Atlantic Coasts: impact on species' abundances. J Plankton Res 33:1654-1665
Post E, Forchhammer MC, Bret-Harte MS, Callaghan TV, Christensen TR, Elberling B, Fox AD, Gilg O, Hik DS, Høye TT, Ims RA, Jeppesen E, Klein DR, Madsen J, McGuire AD, Rysgaard S, Schindler DE, Stirling I, Tamstorf MP, Tyler NJ, van der Wal R, Welker J, Wookey PA, Schmidt NM, Aastrup P (2009) Ecological dynamics across the Arctic associated with recent climate change. Science 325:1355-1358

Renaud PE, Berge J, Varpe $\varnothing$, Lønne OJ, Nahrgang JM, Ottesen C, Hallanger I (2012) Climate change, competition, and consequences for the key Arctic fish, Boreogadus saida. Polar Biol 35:401-412

Reygondeau G, Beaugrand G (2011) Future climate-driven shifts in distribution of Calanus finmarchicus. Glob Change Biol 17:756766

Slagstad D, Ellingsen IH, Wassmann P (2011) Evaluating primary and secondary production in an Arctic Ocean void of summer sea ice: an experimental simulation approach. Progr Oceanogr 90:117-131

Søreide JE, Falk-Petersen S, Hegseth EN, Hop H, Carroll ML, Hobson KA, Blachowiak-Samolyk K (2008) Seasonal feeding strategies of Calanus in the high-Arctic Svalbard region. DeepSea Res Part II Top Stud Oceanogr 55:2225-2244

Steen H, Vogedes D, Broms F, Falk-Petersen S, Berge J (2007) Little auks (Alle alle) breeding in a High Arctic fjord system: bimodal foraging strategies as a response to poor food quality? Polar Res 26:118-125

Tande KS (1991) Calanus in North Norwegian Fjords and in the Barents Sea. Polar Res 10:389-407

Unstad KH, Tande KS (1991) Depth distribution of Calanus finmarchicus and Calanus glacialis in relation to environmental conditions in the Barents Sea. Polar Res 10:409-420

Varpe $\varnothing$ (2012) Fitness and phenology: annual routines and zooplankton adaptations to seasonal cycles. J Plankton Res $34: 267-276$

Varpe $\varnothing$, Fiksen $\varnothing$, Slotte A (2005) Meta-ecosystems and biological energy transport from ocean to coast: the ecological importance of herring migration. Oecologia 146:443-451

Vogedes D, Varpe Ø, Søreide JE, Graeve M, Berge J, Falk-Petersen S (2010) Lipid sac area as a proxy for individual lipid content of arctic calanoid copepods. J Plankton Res 32:1471-1477

Wallace MI, Cottier FR, Berge J, Tarling GA, Griffiths C, Brierley AS (2010) Comparison of zooplankton vertical migration in an ice-free and a seasonally ice-covered Arctic fjord: an insight into the influence of sea ice cover on zooplankton behavior. Limnol Oceanogr 55:831-845

Wassmann P, Reigstad M, Haug T, Rudels B, Carroll ML, Hop H, Gabrielsen GW, Falk-Petersen S, Denisenko SG, Arashkevich E, Slagstad D, Pavlova O (2006) Food webs and carbon flux in the Barents Sea. Progr Oceanogr 71:232-287

Wassmann P, Duarte CM, Agusti S, Sejr MK (2011) Footprints of climate change in the Arctic marine ecosystem. Global Change Biol 17:1235-1249

Weslawski J, Hacquebord L, Stempniewicz L (2000) Greenland whales and walruses in the Svalbard food web before and after exploitation. Oceanologia 42:37-56

Weydmann A, Kwasniewski S (2008) Distribution of Calanus populations in a glaciated fjord in the Arctic (Hornsund, Spitsbergen) - the interplay between biological and physical factors. Polar Biol 31:1023-1035 